\title{
Kesesuaian Taman Cerdas Sebagai Ruang Publik Skala Pelayanan Kelurahan Terhadap Konsep Kota Layak AnaK
}

\author{
RAHMA PUSPITA SARI ${ }^{1}$ \\ PROGRAM STUDI PERENCANAAN WILAYAH DAN KOTA \\ FAKULTAS TEKNIK \\ UNIVERSITAS SEBELAS MARET, SURAKARTA \\ email : rahmapuspitasari948@gmail.com \\ KUSUMASTUTI ${ }^{2}$ \\ PROGRAM STUDI PERENCANAAN WILAYAH DAN KOTA \\ FAKULTAS TEKNIK \\ UNIVERSITAS SEBELAS MARET, SURAKARTA \\ RUfia ANDisetyana PUTRI ${ }^{3}$ \\ PROGRAM STUDI PERENCANAAN WILAYAH DAN KOTA \\ FAKULTAS TEKNIK \\ UNIVERSITAS SEBELAS MARET, SURAKARTA
}

\begin{abstract}
The Child Friendly City (CFC) is a concept for a city that can guarantee children to get their rights in urban area. The Child Friendly City (CFC) is expected for children to get their rights including health, protection, care, education, no discrimination, aware of their environment and culture, participate in designing the city, and have the freedom to play. Surakarta is one of the cities in Indonesia which have applied the concept of Child Friendly City (CFC) since 2008. To support implementation of Child Friendly City (CFC) concept, the city must provide a public space for children to be able to transfer their creativity and also have recreational purpose, which is 'taman cerdas'. The right choice of location, facility, environment, and security need to be considered, because each children go through different phase. The purpose of this study are (1) Knowing the suitability of taman cerdas component as the public space of neighborhood service scale to the concept of Child Friendly Cities (CFC) and (2) Analyze the suitability level of taman cerdas as the public space of neighborhood service scale to the concept of Child Friendly Cities (CFC). The method used in this research is quantitative research with deductive approach, this research used scoring analysis. Survey conducted for this study were primary surveys, consist of observation and interviews, and secondary survey in the form of data. From these results, the advantage of knowing the level of conformity of 'taman cerdas' as the public spaces of neighborhood service to the concept of Child Friendly Cities (CFC) has four variables such as strategic location, facilities for playing and learning according to the needs of children, comfortable and healthy environment, as well as comfort and security. Then those variables are used for the assessment tools to eight 'taman cerdas' in Surakarta. Based on the results of the study, it can be concluded that there are four 'taman cerdas' is match with the variables above, which is 'taman cerdas' Mojosongo, Joyotakan, Pajang, and Jebres. Meanwhile there are also four 'taman cerdas' that not match with the variables of thes research those are 'taman cerdas' Sumber, Gandekan, Kadipiro, and Pucangsawit. The conclusion is the city needs to increase the the component for taman cerdas as public space service scale of neighborhood for Child Friendly Cities (CFC) at Surakarta.
\end{abstract}

Keywords: Child Friendly Cities (CFC), Conformitty, Public Space, Taman Cerdas 



\section{PENDAHULUAN}

Kota merupakan permukiman yang berpenduduk relatif besar, luas areal terbatas, pada umumnya bersifat nonagraris, kepadatan penduduk relatif tinggi, tempat sekelompok orang dengan jumlah penduduk tertentu dan bertempat tinggal dalam suatu wilayah geografis tertentu, cenderung berpola hubungan rasional, ekonomis dan individualis [Ditjen Cipta Karya , 1997]. Berbagai tema kota telah diterapkan untuk menciptakan kenyaman seluruh penghuni perkotaan, salah satunya adalah konsep Child Friendly City (CFC) atau Kota Layak Anak (KLA). Konsep ini merupakan salah satu program UNHABITAT dan UNICEF yang diadopsi dari hasil penelitian Kevin Lynch, arsitek dari Massachusetts Institutes of Technology dengan penelitian berjudul "Persepsi Anak Terhadap Ruang". Dengan adanya konsep Kota Layak Anak (KLA) ini, diharapkan pemerintah dapat mampu memberikan suatu jaminan terhadap hak anak, meliputi kesehatan, perlindungan, perawatan, pendidikan, tidak menjadi korban diskriminasi, mengenal lingkungan dan budayanya, berpartisipasi dalam merencanakan kota tempat tinggalnya, memiliki kebebasan bermain, dan memperoleh lingkungan yang bebas dari polusi Riggio [2002] dan Child Friendly Cities [2011, dalam Widiyanto, 2012]. Di Indonesia, konsep Kota Layak Anak (KLA) diperkenalkan oleh Kementerian Negara Pemberdayaan Perempuan Republik Indonesia Diharapkan konsep Kota Layak Anak (KLA) ini dapat menjadi program serta kegiatan yang dirancang dan dikembangkan pada setiap kabupaten dan kota untuk mendukung terciptanya kota yang layak atau ramah untuk anak.

Pada tahun 2006, Menteri Pemberdayaan Perempuan Republik Indonesia memilih 5 Kabupaten/Kota untuk dijadikan sebagai pilot proyek pengembangan model Kota Layak Anak di Indonesia, salah satunya adalah Kota Surakarta.
Dalam konsep Kota Layak Anak, terdapat 31 indikator yang tercantum dalam Permen No.14 Tahun 2011 tentang Panduan Evaluasi Kota Layak Anak, indikator tersebut yang dibagi menjadi 5 klaster untuk mendukung pencapaian penerapan Kota Layak Anak (KLA), salah satunya adalah pemenuhan fasilitas kegiatan kreatif dan rekreatif yang ramah anak dari klaster pendidikan.

Pada Kota Surakarta dalam pemenuhan fasilitas kegiatan kreatif dan rekreatif yang ramah anak yaitu berupa taman cerdas. Taman cerdas merupakan suatu ruang publik yang dibangun diatas tanah milik pemerintah dengan skala pelayanan kelurahan serta dilengkapi dengan fasilitas yang dapat diakses oleh berbagai kalangan terutama anak - anak Profil Anak Kota Surakarta [2013]. Adapun fasilitas yang tersedia di taman cerdas meliputi ruang perpustakaan, ruang informasi teknologi, panggung seni, dan taman bermain telah tersedia Profil Anak Kota Surakarta [2013]. Pemenuhan fasilitas untuk anak tentu saja berbeda pada setiap tahap pertumbuhan anak Hal ini penting untuk dipertimbangkan dalam penyediaan fasilitas kreatif dan rekreatif yang ramah untuk anak.

Dalam hal ini adalah penyediaan taman cerdas, dengan mempertimbangkan kebutuhan anak berdasarkan fase perkembangannya maka kebutuhan anak untuk bermain dan belajar di taman cerdas akan terpenuhi. Sehingga diperlukan peninjauan terkait kesesuaian taman cerdas sebagai ruang publik skala pelayanan kelurahan untuk mendukung konsep Kota Layak Anak (KLA) dan muncul pertanyaan dalam penelitian "Bagaimana kesesuaian taman cerdas sebagai ruang publik skala pelayanan keluraan terhadap konsep Kota Layak Anak (KLA)?" 


\section{TINJAUUAN PUSTAKA}

\subsection{Ruang Publik}

Ruang publik menurut Darmawan [2005] adalah ruang yang dapat mewadahi kepentingan publik atau masyarakat umum untuk melakukan komunikasi dengan kolega, pertemuan informal komunitas tertentu, bermain, jalan-jalan, melepas lelah, melihat taman dan penghijauan. Selain itu, menurut Carr [1992] dalam bukunya yang berjudul Public Space mengatakan bahwa ruang publik dapat berupa taman umum skala nasional, regional, kabupaten berupa taman kota, sampai taman skala lingkungan yang berada pada kawasan permukiman kota. Berdasarkan beberapa literatur terkait pengertian, ciri, fungsi, dan elemen dari ruang publik maka dapat disimpulkan bahwa kriteria ruang publik, sebagai berikut [Shirvani 1985 dalam Mandai, 2015; Carr,1992; Hakim,1993; Angger Jati, 2004 dalam Djasri 2005 ; Darmawan, 2009 ; UU No.26 Thn 2007 tentang Penataan Ruang; Analisis Penulis, 2017] :

a. Aksesibilitas

b. Fasilitas Ruang Publik, antara lain : tempat duduk, taman, areal parkir, jalan, dan pedestrian.

c. Aktifitas atau kegiatan di ruang publik, antara lain : berkomunikasi dan bersosialisasi, kegiatan ekonomi, berekreasi, bermain, berolahraga, dan endapatkan udara segar.

d. Kenyamanan

\subsection{Kota Layak Anak (KLA)}

Konsep Kota Layak Anak (KLA) pertama kali digagas dari penelitian yang dilakukan oleh Kevin Lynch mengenai "Childern's Perception of the Environment". Penelitian tersebut disponsori oleh UNESCO dalam rangka program Growing Up In Cities (GUIC) pada tahun 1977. Setelah 25 tahun hasil penelitian Kevin Lynch ditinjau kembali, oleh Dr Louise Chawla dari the Childern and environment program of the Norwegian Center for Child Research
Trondheim pada tahun 1994-1995 yang disponsori oleh UNESCO. Kemudian hasil penelitian tersebut dijadikan sebagai indikator oleh UNICEF untuk mengawasi pemenuhan hak anak di perkotaan.

Pada Permen Nomor 11 Tahun 2011 tentang Kebijakan Pengembangan kota layak anak (KLA) dikatakan bahwa kota layak anak adalah suatu kota yang memiliki sistem pembangunan berbasis hak anak melalui pengintegrasian komitmen dan sumberdaya pemerintah, masyarakat dan dunia yang terencana secara menyeluruh dan berkelanjutan dalam kebijakan, program dan kegiatan untuk menjamin terpenuhinya hak anak. Hal tersebut sejalan dengan pendapat Joga [2013] bahwa Kota Layak Anak (KLA) adalah sistem pembangunan kabupaten/kota yang mengintegrasikan komitmen dan sumberdaya pemerintah, masyarakat dan dunia usaha yang terencana serta menyeluruh dan berkelanjutan dalam kebijkan, program dan kegiatan untuk pemenuhan hak-hak anak. Berdasarkan beberapa literatur terkait pengertian, tujuan, fungsi dari Kota Layak Anak (KLA) maka diperoleh bahwa kriteria Kota Layak Anak (KLA) berdasarkan [Riggio 2002 dalam Widiyanto,2012; Joga, 2013; BP3AKN ,2013;Permen Nomor. 11 Tahun 2011 tentang Kebijakan Pengembangan kota layak anak; UNICEF,2004; Analisis Penulis, 2017] :

a. Pembangunan perkotaan yang mempertimbangkan hak anak

b. Kemudahan untuk menggunakan fasilitas umum

c. Keamanan

d. Kenyamanan

\subsection{Taman Cerdas}

Taman cerdas adalah salah satu upaya pemerintah Kota Surakarta dalam mewujudkan Surakarta sebagai Kota Layak Anak (KLA). Pada indikator Kota Layak Anak (KLA), taman cerdas masuk kedalam klaster keempat yaitu klaster pendidikan dan penyediaan fasilitas kegiatan kreatif dan rekreatif anak. 
Pemenuhan kegiatan kreatif dan rekreatif yang ramah anak diluar sekolah yang mampu diakses oleh semua anak berupa taman cerdas.

Taman cerdas memiliki standar minimal fasilitas yang harus tersedia berdasarkan Peraturan Walikota Surakarta No. 6 Tahun 2008 tentang Petunjuk Pelaksanaan Pengelolaan Taman Cerdas di Kota Surakarta, antara lain ruang perpustakaan, ruang informasi teknologi (IT), panggung seni dan kreatifitas/pengembangan bakat adalah tempat untuk berlatih seni (tari, nyanyi, teater, dll) dan tempat untuk menggambar atau membuat suatu keterampilan, taman bermain dan alat bermain adalah tempat yang telah disediakan alat-alat bermain (ayunan, trowongan, panjatan, danperosotan, dll), ruang untuk olah raga, kamar mandi dan wc. Saat ini, terdapat 8 taman cerdas yang telah tersebar di Kota Surakarta, antara lain Kelurahan Sumber, Mojosongo, Joyontakan, Pajang, Gandekan, Kadipiro, Pucang Sawit, dan Jebres. Berikut merupakan kriteria taman cerdas berdasarkan beberapa literatur [Peraturan Walikota Surakarta No. 6 Tahun 2008 tentang Petunjuk Pelaksanaan Pengelolaan Taman Cerdas di Kota Surakarta; Analisis Penulis, 2017):

a. Jangkauan pelayanan skala kelurahan

b. Lokasi strategis

c. Aktifitas edukasi, rekreasi, dan kreatif

d. Fasilitas penunjang kegiatan edukasi, rekreasi, kreatif, dan pengembangan dan bakat.

Pelayanan taman cerdas sebagai ruang publik skala pelayanan kelurahan yaitu melayani sebanyak 30.000 jiwa pada setiap kelurahan berdasarkan Peraturan Menteri Pekerjaan Umum Nomor 05/PRT/M/2008 tentang Pedoman Penyediaan dan Pemanfaatan Ruang Terbuka Hijau di Kawasan Perkotaan. Pada buku Housing and Residential
Development de Chiara et al. [1995] taman dengan pelayanan sebanyak 30.000 jiwa setara dengan community park and playfield, yang mempunyai radius pelayanan sebesar $1 \frac{1}{2}$ miles atau setara dengan 2.414 meter. Kriteria taman cerdas sebagai ruang publik skala pelayanan kelurahan berdasarkan tinjauan literatur [Joga, 2013; BP3AKN,2013 ; Permen Nomor. 11 Tahun 2011 tentang Kebijakan Pengembangan Kota Layak Anak; UNICEF,2004; Peraturan Walikota Surakarta Nomor 6 Tahun 2008 tentang Petunjuk Pelaksanaan Pengelolaan Taman Cerdas Kota Surakarta; Carr,1992; Analisis Penulis, 2017] :

a. Lokasi strategis dan mudah diakses untuk mendukung kegiatan edukasi, rekreasi, dan kreatif

b. Fasilitas penunjang kegiatan berkomunikasi, bejar, kegiatan ekonomi, berekreasi, bermain, dan berolahraga

c. Kenyamanan dalam melakukan kegiatan dan menggunakan fasilitas penunjang kegiatan edukasi,rekreasi, kreatif, dan pengembangan bakat

Perumusan kriteria taman cerdas sebagai ruang publik skala pelayanan kelurahan terhadap konsep Kota Layak Anak (KLA) didasarkan antara kriteria taman cerdas sebagai ruang publik skala pelayanan kelurahan dan kriteria Kota Layak Anak (KLA) berdasarkan tinjauan literatur [Joga, 2013; BP3AKN ,2013 ; Permen Nomor. 11 Tahun 2011 tentang Kebijakan Pengembangan kota layak anak; UNICEF,2004; Peraturan Walikota Surakarta Nomor 6 Tahun 2008 tentang Petunjuk Pelaksanaan Pengelolaan Taman Cerdas Kota Surakarta; Car,1992; Analisis Penulis, 2017] :

a. Lokasi strategis dan mudah diakses

b. Fasilitas yang ramah anak di perkotaan yang mendukung anak untuk berkomunikasi, belajar, kegiatan ekonomi, berekreasi, bermain, dan berolahraga 
c. Keamanan dalam menjangkau fasilitas penunjang kegiatan anak

d. Keamanan dan kenyamanan untuk melakukan kegiatan edukasi,rekreasi, kreatif, dan pengembangan bakat

e. Lingkungan yang nyaman dan sehat

\subsection{Kebutuhan Anak berdasarkan Fase Perkembangan Anak}

Target utama taman cerdas sebagai fasilitas untuk mewadahi anak dalam pemenuhan kegiatan kreatif dan rekreatif yang ramah anak diluar sekolah adalah anak - anak. Pada Peraturan Walikota Surakarta Nomor 6 Tahun 2008 tentang Petunjuk Pelaksanaan Pengelolaan Taman Cerdas Surakarta dikatakan bahwa fasilitas taman cerdas diperuntukan untuk anakanak, serta dikatakan bahwa anak adalah seorang yang belum berusia 0-18 tahun. Yusuf [2004] membagi fase perkembangan anak menjadi tiga bagian yaitu masa usia pra sekolah 0-6 tahun, sekolah dasar 6-12 tahun, dan 1218 tahun setiap anak memiliki fase perkembangan anak yang berbeda beda sehingga kebutuhan ruang setiap anak pun berbeda beda.

\subsection{Ruang Untuk Anak Berdasarkan Fase Perkembangannya}

Menurut Bartlett [2002] keberadaan suatu ruang yang aman untuk anak serta dapat menjamin keselamatan anak ketika melewati jalan dapat meningkatkan kesempatan untuk hak bermain dan berinteraksi. Bartlett [2002] membaginya menjadi beberapa fase meliputi ketika anak masih berusia kecil, anak mulai tumbuh, anak mulai remaja. Berikut merupakan kebutuhan ruang anak berdasarkan fase perkembangan anak yang diperoleh dari kriteria fase pertumbuhan anak setiap usia dan hak anak untuk bermain dari beberapa literatur [Yusuf, 2004; Havighust, 1961 dalam Hastuti, 2012; Hurlock, 1999 dalam Hastuti, 2012; Suherman, 2000 dalam Hastuti, 2012; Rahayu, 2014; Analisis Penulis, 2017] :

1) Kebutuhan Ruang Anak Berdasarkan Usia 0-6 Tahun

- Lokasi bermain di sekitar rumah yang nyaman untuk anak mengeksplorasi ruang dan bermain teman seusianya

- Permainanan yang mendukung penggunaan pancaindera dan melakukan keterampilan fisik

- Lingkungan yang mewadahi anak untuk berinteraksi dengan orang lain dan beradaptasi dengan teman seusianya

- Terdapat permainan yang dapat mendukung anak dalam mengembangkan keterampilan membaca, menulis, menghitung

2) Kebutuhan Ruang Anak Berdasarkan Usia 6-12 Tahun

- Kemudahan akses dalam menjangkau ruang publik untuk mendukung kegiatan bermain dengan teman - temannya

- Lingkungan sekitar rumah yang aman dan nyaman untuk bermain dengan teman- temannya

- Lingkungan dan alat bermain yang mendukung permainan aktif

- Ruang yang mendukung anak bermain aktif dengan teman seusianya

- Permainan yang mendorong anak untuk menyelesaikan permasalahan melalui permainan tersebut

3) Kebutuhan Ruang Anak Berdasarkan Usia 12-18 Tahun

- Adanya kebebasan anak untuk menggunakan transportasi yang mudah dijangkau dan terintegrasi

- Terdapat fasilitas untuk pengembangan bakat dan cita cita, rekreasi, dan bermain dalam mendukung pertumbuhan dan perkembangan fisik

- Ruang publik yang memfasilitasi untuk berkumpul dengan teman - 
temannya dalam suatu norma norma kesusilaan

\section{METODE PENELITIAN}

Penelitian kesesuaian taman cerdas sebagai ruang publik skala pelayanan kelurahan terhadap Konsep Kota Layak Anak (KLA) bertujuan untuk mengetahui tingkat kesesuaian taman cerdas sebagai ruang publik skala pelayanan kelurahan terhadap konsep Kota Layak Anak (KLA) di Kota Surakarta. Sedangkan untuk sasaran penelitian ini sebagai berikut :

- Mengidentifikasi kesesuaian komponen dan menganalisis tingkat kesesuaian taman cerdas sebagai ruang publik skala pelayanan kelurahan terhadap konsep Kota Layak Anak (KLA) di Surakarta

- Menganalisis tingkat kesesuaian taman cerdas sebagai ruang publik skala pelayanan kelurahan dalam konsep Kota Layak Anak (KLA).

\subsection{Variabel Penelitian}

Variabel tingkat kesesuaian taman cerdas sebagai ruang publik terhadap konsep Kota Layak Anak (KLA), meliputi lokasi strategis, fasilitas bermain dan belajar sesuai dengan kebutuhan anak, lingkungan yang nyaman dan sehat, serta kenyamanan dan keamanan.

Tabel 1 Variabel Penelitian Kesesuaian Taman Cerdas sebagai Ruang Publik Skala Pelayanan Kelurahan terhadap Konsep Kota Layak Anak (KLA)

\begin{tabular}{|l|l|ll|}
\hline No & \multicolumn{1}{|c|}{ Variabel } & Sub Variabel \\
\hline 1. & $\begin{array}{l}\text { Lokasi yang } \\
\text { strategis }\end{array}$ & $\begin{array}{l}\text { Lokasi taman cerdas } \\
\text { mudah diakses }\end{array}$ \\
& $\begin{array}{l}\text { Jangkauan } \\
\text { pelayanan taman } \\
\text { untuk anak } \\
\text { Terdapat } \\
\text { transpotasi umum } \\
\text { yang terintegrasi } \\
\text { menuju taman }\end{array}$ \\
\hline 2. & $\begin{array}{l}\text { Fasilitas } \\
\text { bermain dan } \\
\text { belajar sesuai } \\
\text { dengan } \\
\text { kebutuhan } \\
\text { anak }\end{array}$ & $\begin{array}{l}\text { 1. } \\
\text { 2. }\end{array}$ & $\begin{array}{l}\text { Fasilitas Bermain } \\
\text { Fasilitas } \\
\text { Belajar/Edukasi } \\
\text { Fasilitas untuk } \\
\text { mengembangan } \\
\text { bakat }\end{array}$ \\
\hline
\end{tabular}

\begin{tabular}{|c|c|c|}
\hline No & Variabel & Sub Variabel \\
\hline & & $\begin{array}{ll}\text { 5. Fasilitas untuk } \\
\text { melakukan } \\
\text { permainan aktif }\end{array}$ \\
\hline 3. & $\begin{array}{l}\text { Lingkungan } \\
\text { yang nyaman } \\
\text { dan sehat }\end{array}$ & $\begin{array}{ll}\text { 1. } & \text { Ketersediaan } \\
\text { vegetasi } \\
\text { 2. Terdapat ruang } \\
\text { untuk berinteraksi }\end{array}$ \\
\hline 4. & $\begin{array}{l}\text { Kenyaman dan } \\
\text { Keamanan }\end{array}$ & $\begin{array}{ll}\text { 1. } & \text { Jalur Pejalan Kaki } \\
\text { 2. Pembatas Ruang } \\
\text { 3. Petugas Keamanan } \\
\text { 4. Pengelola taman } \\
\text { 5erdas } \\
\text { 5. Fasilitas Kebersihan } \\
\text { 6. Petugas Kebersihan } \\
\text { 7. Area Parkir }\end{array}$ \\
\hline
\end{tabular}

Sumber : Analisis Penulis, 2017

Pada penilaian tingkat kesesuaian taman cerdas sebagai ruang publik skala pelayanan kelurahan dalam konsep Kota Layak Anak (KLA), nilai yang digunakan pada penelitian ini adalah 1 "sesuai" dan 0 "tidak sesuai" berikut merupakan indikator yang akan digunakan dalam penilaian setiap taman cerdas di Kota Surakarta.

Tabel 2 Tingkat Kesesuaian Taman Cerdas berdasarkan Lokasi

\begin{tabular}{|c|c|}
\hline Sub Variabel & Indikator \\
\hline \multirow{3}{*}{$\begin{array}{l}\text { Lokasi taman cerdas } \\
\text { mudah diakses }\end{array}$} & $\begin{array}{l}\text { Bagian dari suatu jalan atau } \\
\text { jalur sirkulasi }\end{array}$ \\
\hline & $\begin{array}{l}\text { Taman dapat diakses secara } \\
\text { visual }\end{array}$ \\
\hline & $\begin{array}{l}\text { Terdapat fasilitas umum } \\
\text { disekitar taman cerdas } \\
\text { (dengan radius } 400 \text { meter } \\
\text { dari taman cerdas) }\end{array}$ \\
\hline $\begin{array}{l}\text { Jangkauan pelayanan } \\
\text { taman untuk anak } \\
\text { skala pelayanan } \\
\text { kelurahan }\end{array}$ & $\begin{array}{l}\text { Jangkauan pelayanan } \\
\text { taman skala pelayanan } \\
\text { kelurahan sebesar } 2.141 \\
\text { meter }\end{array}$ \\
\hline \multirow{2}{*}{$\begin{array}{l}\text { Terdapat transportasi } \\
\text { umum yang } \\
\text { terintegrasi menuju } \\
\text { taman }\end{array}$} & $\begin{array}{l}\text { Terdapat transportasi } \\
\text { umum menuju taman cerdas }\end{array}$ \\
\hline & $\begin{array}{l}\text { Terdapat tempat transit } \\
\text { (halte) dengan radius } 400 \\
\text { meter disekitar taman } \\
\text { cerdas. }\end{array}$ \\
\hline
\end{tabular}

Sumber : Analisis Penulis, 2017 
Tabel 3 Tingkat Kesesuaian Taman Cerdas Berdasarkan Fasilitas Bermain sesuai dengan Kebutuhan Anak

\begin{tabular}{|l|l|}
\hline \multicolumn{1}{|c|}{ Sub Variabel } & \multicolumn{1}{|c|}{ Indikator } \\
\hline \multirow{2}{*}{ Fasilitas Bermain } & $\begin{array}{l}\text { Fasilitas fermain } \\
\text { mengunakan panca indera }\end{array}$ \\
\cline { 2 - 2 } & $\begin{array}{l}\text { Ketersediaan fasitas } \\
\text { bermain anak }\end{array}$ \\
\hline \multirow{2}{*}{$\begin{array}{l}\text { Fasilitas } \\
\text { Belajar/Edukasi }\end{array}$} & Ruang Perpustakaan \\
\cline { 2 - 2 } $\begin{array}{l}\text { Fasilitas } \\
\text { mengembangkan } \\
\text { bakat }\end{array}$ & $\begin{array}{l}\text { Terdapat panggung seni } \\
\text { kreatifitas/pengembangan } \\
\text { bakat atau area pertunjukan }\end{array}$ \\
\hline \multirow{2}{*}{ Fasilitas Rekreasi } & $\begin{array}{l}\text { Tersedia ruang untuk } \\
\text { bermain dan melakukan } \\
\text { permainan aktif }\end{array}$ \\
\cline { 2 - 2 } & Lapangan olah raga \\
\hline
\end{tabular}

Sumber : Analisis Penulis, 2017

Tabel 4 Tingkat Kesesuaian Taman Cerdas Berdasarkan Lingkungan yang Nyaman dan Sehat

\begin{tabular}{|l|l|}
\hline \multicolumn{1}{|c|}{ Sub Variabel } & \multicolumn{1}{c|}{ Indikator } \\
\hline $\begin{array}{l}\text { Ketersediaan } \\
\text { vegetasi }\end{array}$ & Ketersediaan vegetasi \\
\hline \multirow{4}{*}{$\begin{array}{l}\text { Terdapat ruang } \\
\text { untuk berinteraksi }\end{array}$} & Ketersediaan area bermain \\
\cline { 2 - 2 } & \begin{tabular}{l} 
Terdapat area duduk \\
\cline { 2 - 2 }
\end{tabular} \\
\cline { 2 - 2 } & $\begin{array}{l}\text { Terdapat jalan setapak berkeliling taman } \\
\text { (Pathways) }\end{array}$ \\
\cline { 2 - 2 } & Fasilitas air minum \\
\hline
\end{tabular}

Sumber : Analisis Penulis, 2017

Tabel 5 Tingkat Kesesuaian Taman Cerdas berdasarkan Kenyamanan dan Keamanan

\begin{tabular}{|l|l|}
\hline \multicolumn{1}{|c|}{ Sub Variabel } & \multicolumn{1}{c|}{ Indikator } \\
\hline \multirow{3}{*}{ Jalur pejalan kaki } & $\begin{array}{l}\text { Tersedia jalur pejalan kaki } \\
\text { atau trotoar disekeliling } \\
\text { taman cerdas }\end{array}$ \\
\hline \multirow{2}{*}{ Pembatas Ruang } & Pagar pembatas taman \\
\cline { 2 - 2 } Petugas Keamanan & Pagar pembatas taman \\
\hline \multirow{2}{*}{$\begin{array}{l}\text { Pengelola taman } \\
\text { cerdas }\end{array}$} & $\begin{array}{l}\text { Pengelola ruang } \\
\text { perpustakaan }\end{array}$ \\
\cline { 2 - 2 } & $\begin{array}{l}\text { Pengelola ruang teknologi } \\
\text { informasi }\end{array}$ \\
\hline \multirow{3}{*}{ Fasilitas Kebersihan } & Tempat sampah \\
\cline { 2 - 2 } & $\begin{array}{l}\text { Terdapat petugas } \\
\text { kebersihan }\end{array}$ \\
\hline \multirow{2}{*}{ Area Parkir } & $\begin{array}{l}\text { Terdapat khusus untuk } \\
\text { parkir kendaraan } \\
\text { pengunjung taman }\end{array}$ \\
\hline
\end{tabular}

Sumber : Analisis Penulis, 2017

\subsection{Teknik Analisis}

Pada penelitian ini, teknik analisis yang akan digunakan adalah teknik analisis skoring. Teknik analisis skoring adalah memberikan nilai (skor) pada setiap indikator yang telah ditentukan untuk menilai kondisi di lapangan terdapat dua tahap penilian yaitu penilaian setiap komponen serta penilaian pada masing - masing variabel, sehingga akan didapat kan nilai sesuai atau tidak sesuai pada setiap taman cerdas di Kota Surakarta.

\subsubsection{Identifikasi Kesesuaian Komponen Taman Cerdas Sebagai Ruang Publik Skala Pelayanan Kelurahan Terhadap Konsep Kota Layak Anak (KLA)}

Identifikasi ketersediaan komponen taman cerdas sebagai ruang publik skala pelayanan kelurahan terhadap konsep Kota Layak Anak (KLA) yang ditinjau dari empat variabel penelitian, meliputi lokasi strategis, fasilitas bermain sesuai dengan kebutuhan anak, lingkungan yang nyaman dan sehat, serta kenyamanan dan keamanan. Variabel penelitian tersebut telah dijabarkan melalui beberapa indikator dan masing - masing indikator tersebut dinilai berdasarkan kondisi dilapangan, dimana bernilai 1 jika "sesuai" dan bernilai 0 jika "tidak sesuai". Penilaian tersebut digunakan untuk mengetahui kesesuaian komponen taman cerdas sebbagai ruang publik skala pelayanan kelurahan terhadap konsep Kota Layak Anak (KLA) maka dilakukan penilaian pada setiap sub variabel, dengan rumus sebagai berikut.

interval $=\frac{(\text { nilai maksimum })-(\text { nilai minimum })}{\text { jumlah kelas }}$

Interval : $\mathrm{x}$

Tabel 6. Nilai Kesesuaian Komponen Taman Cerdas

\begin{tabular}{|l|c|c|}
\hline \multicolumn{1}{|c|}{$\begin{array}{c}\text { Nilai Kesesuaian } \\
\text { Komponen }\end{array}$} & Nilai & Keterangan \\
\hline $\begin{array}{l}\text { Total nilai (nilai minimum+ } \\
+0,1)-(\text { nilai maksimum) }\end{array}$ & 1 & Sesuai \\
\hline $\begin{array}{l}\text { Total skor (nilai minimum) - } \\
\text { (nilai minimum+ } \mathbf{x} \text { ) }\end{array}$ & 0 & Tidak Sesuai \\
\hline
\end{tabular}

Sumber : Analisis Penulis, 2017 
Selanjutnya, dengan rumus yang sama dilakukan penilaian tingkat kesesuaian pada masing-masing variabel (lokasi strategis, fasilitas bermain sesuai dengan kebutuhan anak, lingkungan yang nyaman dan sehat, serta kenyamanan dan keamanan).

\subsubsection{Tingkat Kesesuaian Taman Cerdas sebagai Ruang Publik Skala Pelayanan Kelurahan terhadap Konsep Kota Layak Anak (KLA) di Kota Surakarta}

Tingkat Kesesuaian Taman Cerdas sebagai ruang publik skala pelayanan kelurahan terhadap konsep kota layak anak (KLA) di Kota Surakarta diidentifikasi berdasar nilai hasil kesesuaian dari empat variabel meliputi lokasi strategis, fasilitas bermain sesuai dengan kebutuhan anak, lingkungan yang nyaman dan sehat, serta kenyamanan dan keamanan dengan pendekatan kuantitatif kedelapan taman cerdas yang tersedia di Kota Surakarta dinilai berdasarkan variabel tersebut sehingga dapat diketahui tingkat kesesuaian taman cerdas di Kota Surakarta.

\section{HASIL DAN PEMBAHASAN}

4.1 Kesesuaian Komponen Taman Cerdas sebagai Ruang Publik Skala Pelayanan Kelurahan terhadap konsep Kota Layak Anak (KLA)

Berdasarkan analisis yang telah dilakukan, didapatkan nilai untuk masing-masing variabel taman cerdas sebagai Ruang Publik Skala Pelayanan Kelurahan Terhadap Konsep Kota Layak Anak (KLA) sebagai berikut :

Tabel 7. Nilai Kesesuaian Lokasi Strategis

\begin{tabular}{|c|l|c|c|}
\hline No & Taman Cerdas & Nilai & Kesesuaian \\
\hline 1 & Sumber & 1 & Sesuai \\
\hline 2 & Mojosongo & 1 & Sesuai \\
\hline 3 & Joyontakan & 1 & Sesuai \\
\hline 4 & Pajang & 1 & Sesuai \\
\hline 5 & Gandekan & 1 & Sesuai \\
\hline 6 & Kadipiro & 0 & Tidak Sesuai \\
\hline 7 & Pucang Sawit & 1 & Sesuai \\
\hline 8 & Jebres & 1 & Sesuai \\
\hline \multicolumn{2}{|c|}{ Total } & 7 & \\
\hline
\end{tabular}

Sumber : Analisis Penulis, 2017
Pada penilaian kesuaian lokasi strategis pada setiap taman cerdas, dapat disimpulkan bahwa terdapat 7 taman cerdas yang telah sesuai dan 1 taman cerdas tidak sesuai yaitu pada taman cerdas Kelurahan Kadipiro. $\mathrm{Hal}$ ini disebabkan karena taman cerdas Kelurahan Kadipiro jangkauan pelayanananya belum dapat menjangkau seluruh wilayah Kelurahan Kadipiro.

Tabel 8. Nilai Kesesuaian Fasilitas Bermain dan Belajar sesuai Kebutuhan Anak

\begin{tabular}{|l|l|c|c|}
\hline No & Taman Cerdas & Nilai & Keterangan \\
\hline 1 & Sumber & 1 & Sesuai \\
\hline 2 & Mojosongo & 1 & Sesuai \\
\hline 3 & Joyontakan & 0 & Tidak Sesuai \\
\hline 4 & Pajang & 0 & Tidak Sesuai \\
\hline 5 & Gandekan & 0 & Tidak Sesuai \\
\hline 6 & Kadipiro & 0 & Tidak Sesuai \\
\hline 7 & Pucang Sawit & 1 & Sesuai \\
\hline 8 & Jebres & 1 & Sesuai \\
\hline \multicolumn{4}{|c|}{ Total Sumber : Analisis Penulis, 2017 } \\
\hline \multicolumn{4}{|c|}{}
\end{tabular}

Tingkat kesesuaian penyediaan fasilitas bermain dan belajar sesuai dengan kebutuhan anak dapat disimpulkan bahwa dapat 4 taman cerdas sesuai dan 4 taman cerdas tidak sesuai. Hal ini disebabkan belum terpenuhinya penyediaan fasilitas bermain anak untuk melatih panca indera.

Tabel 9. Nilai Kesesuaian Lingkungan yang Nyaman dan Sehat

\begin{tabular}{|c|c|c|c|}
\hline No & Jenis Pelayanan & Nilai & Keterangan \\
\hline 1 & Sumber & 1 & Sesuai \\
\hline 2 & Mojosongo & 1 & Sesuai \\
\hline 3 & Joyontakan & 1 & Sesuai \\
\hline 4 & Pajang & 1 & Sesuai \\
\hline 5 & Gandekan & 1 & Sesuai \\
\hline 6 & Kadipiro & 0 & Tidak Sesuai \\
\hline 7 & Pucang Sawit & 0 & Tidak Sesuai \\
\hline 8 & Jebres & 1 & Tidak Sesuai \\
\hline \multicolumn{2}{|r|}{ Total } & 6 & \\
\hline
\end{tabular}

Sumber : Analisis Penulis, 2017

Pada tingkat kesesuaian lingkungan yang nyaman dan sehat terdapat 5 taman cerdas sesuai dan 3 taman cerdas tidak sesuai yaitu pada Taman Cerdas Kelurahan Kadipiro, Pucang Sawit, dan Jebres. Hal ini disebabkan kurang 
terpenuhinya penyediaan ruang untuk berinteraksi pada taman cerdas.

Tabel 10. Nilai Kesesuaian Kenyamanan dan Keamanan

\begin{tabular}{|c|l|c|c|}
\hline No & Jenis Pelayanan & Nilai & Keterangan \\
\hline 1 & Sumber & 1 & Sesuai \\
\hline 2 & Mojosongo & 0 & Tidak Sesuai \\
\hline 3 & Joyontakan & 0 & Tidak Sesuai \\
\hline 4 & Pajang & 1 & Sesuai \\
\hline 5 & Gandekan & 1 & Sesuai \\
\hline 6 & Kadipiro & 1 & Sesuai \\
\hline 7 & Pucang Sawit & 1 & Sesuai \\
\hline 8 & Jebres & 1 & Sesuai \\
\hline \multicolumn{2}{|c|}{ Total } & 6 & \\
\hline
\end{tabular}

Sumber : Analisis Penulis, 2017

Pada tingkat kesesuaian kenyamanan dan keamanan pada taman cerdas belum seluruhnya terpenuhi terdapat 6 taman cerdas sesuai dan 2 taman cerdas tidak sesuai. Hal ini disebabkan kurang terpenuhinya penyediaan jalur pejalan kaki, pembatas ruang, serta area parkir pada taman cerdas.

\subsection{Tingkat Kesesuaian Taman} Cerdas sebagai Ruang Publik Skala Pelayanan Kelurahan terhadap Konsep Kota Layak Anak di Surakarta Pada analisis tingkat kesesuaian taman cerdas sebagai ruang publik skala pelayanan kelurahan terhadap konsep kota layak anak adalah dilakukan perhitungan nilai pada setiap variabel penelitian yang telah ditentukan antara lain lokasi strategis, fasilitas bermain sesuai dengan kebutuhan anak, lingkungan yang nyaman dan sehat, serta kenyamanan dan keamanan, berikut merupakan hasilnya

Tabel 1 1. Tingkat Kesesuaian Taman Cerdas sebagai ruang publik skala pelayanan kelurahan terhadap konsep Kota Layak Anak

\begin{tabular}{|l|l|c|c|}
\hline No & Taman Cerdas & Nilai & Keterangan \\
\hline 1 & Sumber & 0 & Tidak Sesuai \\
\hline 2 & Mojosongo & 1 & Sesuai \\
\hline 3 & Joyontakan & 1 & Sesuai \\
\hline 4 & Pajang & 1 & Sesuai \\
\hline 5 & Gandekan & 0 & Tidak Sesuai \\
\hline 6 & Kadipiro & 0 & Tidak Sesuai \\
\hline 7 & Pucang Sawit & 0 & Tidak Sesuai \\
\hline 8 & Jebres & 1 & Sesuai \\
\hline \multicolumn{2}{|c|}{ Total } & & \\
\hline
\end{tabular}

Sumber : Analisis Penulis, 2017
Sehingga dapat diketahui bahwa tingkat kesesuaian taman cerdas di kota Surakarta sebagai ruang publik skala pelayanan kelurahan terhadap konsep Kota Layak Anak (KLA) 4 taman cerdas "sesuai" yaitu berada pada taman cerdas Kelurahan Mojosongo, Joyontakan, Pajang, dan Jebres. Sedangkan untuk taman cerdas "tidak sesuai" sebanyak 4 taman yaitu berada pada taman cerdas Kelurahan Sumber, Gandekan, Kadipiro, dan Pucang Sawit. $\mathrm{Hal}$ ini disebabkan karena secara garis besar keempat taman tersebut belum sesuai dalam penyediaan komponen fasilitas bermain dan belajar sesuai kebutuhan anak serta keamanan dan kenyamanan pada taman cerdas. Sehingga perlunya penyediaan fasilitas bermain dan belajar sesuai dengan kebutuhan anak serta pejyediaan fasilitas untuk meningkatkan kenyamanan serta kemamanan bagi anak untuk bermain dan belajar di taman cerdas.

\section{KESIMPULAN}

\subsection{Kesimpulan}

Penelitian kesesuaian taman cerdas sebagai ruang publik skala pelayanan kelurahan terhadap konsep Kota Layak Anak (KLA) di Kota Surakarta selama proses penelitian dan berdasarkan analisis menemukan beberapa hal dan dapat ditarik kesimpulan sebagai berikut :

a. Kesesuaian komponen taman cerdas sebagai ruang publik skala pelayanan kelurahan terhadap konsep Kota Layak Anak (KLA) ditinjau berdasarkan empat komponen meliputi lokasi strategis, fasilitas bermain sesuai dengan kebutuhan anak, lingkungan yang nyaman dan sehat, serta kenyamanan dan keamanan Berdasarkan hasil analisis diketahui bahwa belum seluruh taman cerdas telah sesuai dengan komponen tersebut. 
b. Komponen lokasi strategis pada taman cerdas sebagai ruang publik skala pelayanan kelurahan terhadap konsep Kota Layak Anak (KLA) yang ditinjau dari kemudahan dalam mengakses taman cerdas baik fisik maupun visual, jangkauan pelayanan taman untuk anak skala pelayanan kelurahan, serta kertersediaan transportasi umum untuk menjangkau taman cerdas. Berdasarkan hasil penilaian, bahwa terdapat satu taman cerdas yang belum sesuai yaitu taman cerdas kelurahan kadipiro dikarenakan jangkauan pelayanan taman cerdas kadipiro tidak dapat melayani seluruh Kelurahan Kadipiro.

c. Komponen fasilitas bermain dan belajar sesuai dengan kebutuhan anak pada taman cerdas, komponen tersebut ditinjau berdaskarkan ketersediaan permainan melatih panca indera, fasilitas bermain, ruang perpustakaan (luas, jumlah koleksi buku, ketersediaan ruang koleksi buku, ketersediaan ruang pembaca), ruang Komputer serta fasilitas pendukung berupa seperangkat alat PC, fasilitas pengebangan bakat, serta fasilitas rekreasi. Berdasarkan penilaian indikator tersebut dapat disimpulakan bahwa terdapat empat taman cerdas yang belum sesuai yaitu pada taman cerdas Kelurahan Joyontakan, Pajang, Gandekan, dan Kadipiro. Hal tersebut dikarenakan belum terpenuhinya fasilitas penunjang anak untuk bermain dan belajar di taman cerdas yang sesuai dengan kebutuhan anak terutama untuk penyediaan fasilitas permainan untuk melatih panca indera.

d. Komponen lingkungan yang nyaman dan sehat pada taman cerdas ditinjau dari ketersediaan vegetasi dan ketersediaan ruang untuk berinteraksi yang kemudian dijabarkan menjadi beberapa indikator. Bedasarkan hasil penilaian, terdapat dua taman cerdas yang tidak sesuai yaitu taman cerdas Kelurahan
Kadipiro dan Pucang Sawit dikarenakan belum terpenuhinya ruang untuk berinteraksi berupa tempat duduk pada taman serta ketersediaan jalan setapak (pathways).

e. Komponen keamanan dan kenyamanan pada taman cerdas ditinjau dari ketersediaan jalur pejalan kaki, pembatas ruang, pengurus dan pengelola taman cerdas, fasilitas kebersihan, petugas keamanan, serta ketersediaan area parkir. Berdasarkan indikator tersebut dapat disimpulkan bahwa terdapat dua taman cerdas yang belum sesuai yaitu pada taman cerdas Kelurahan Mojosongo dan Joyon 80 dikarenakan belum tersed. pembatas antar ruang di dalam taman cerdas yang tentusaja akan membahayakan anak ketika bermain.

f. Tingkat kesesuaian taman cerdas sebagai ruang publik skala pelayanan kelurahan terhadap konsep Kota Layak Anak (KLA) yang ditinjau berdasarkan komponen lokasi strategis, fasilitas bermain sesuai dengan kebutuhan anak, lingkungan yang nyaman dan sehat, serta kenyamanan dan keamanan, terdapat 4 taman cerdas yang tidak sesuai yaitu berada pada Kelurahan Sumber, Gandekan, Kadipiro, dan Pucang Sawit. Hal ini disebabkan karena secara garis besar keempat taman tersebut belum sesuai dalam penyediaan komponen fasilitas bermain dan belajar sesuai kebutuhan anak serta keamanan dan kenyamanan pada taman cerdas. Selain itu, terdapat 4 taman cerdas yang telah sesuai yaitu taman cerdas Kelurahan Mojosongo, Joyontakan, Pajang, dan Jebres karena keempat taman cerdas tersebut telah memenuhi seluruh komponen.

g. Untuk meningkatkan tingkat kesesuaian taman cerdas sebagai ruang publik skala pelayanan kelurahan terhadap konsep Kota Layak Anak (KLA), maka diperlukan 
penambahan fasilitas bermain dan belajar sesuai dengan kebutuhan anak, mengaktifkan kembali kegiatan rutin pengembangan bakat untuk anak seperti permainan musik gamelan, tari tradisional, dan drama, serta pemeliharahan fasilitas bermain yang tersedia di taman cerdas sehingga tidak mebahayakan anak ketika bermain.

\subsection{Saran}

Saran yang dapat peneliti sampaiakan setalah melakukan proses penelitian ini antara lain sebagai berikut :

a. Perlunya penambahan fasilitas bermain sesuai dengan kebutuhan

$81 \mathrm{k}$ terutama penyediaan fasilitas main untuk melatih panca indera anak.

b. Perlu adanya pemeliharaan ataupun peremajaan fasilitas bermain anak untuk permainan aktif sehingga tdak membahayakan anak ketika bermain.

c. Penambahan koleksi buku sesuai dengan standar penyediaan koleksi buku pada perpustakaan skal pelayanan kelurahan.

d. Penyediaan bangku taman yang dapat mewadahi pengnjung untuk berinterksi serta memasilitasi orang tua untuk mengawasi anak ketika bermain di area bermain.

e. Penyediaan jalur pejalan kaki terutama pada taman cerdas yang berbatasan langsung dengan jalan lokal, sehingga dapat memberikan keamanan dan kenyamanan bagi pengunjung terutama anak-anak.

f. Penyediaan area khusus parkir untuk pengunjung taman cerdas sehingga tidak mengagangu aktifitas di dalam taman cerdas serta tidak menimbulkan kemacetan pada jalan disekitar taman cerdas

g. Untuk penelitian selanjutnya dapat meneliti faktor-faktor yang mempengaruhi keberhasilan taman cerdas dalam mewujudkan Kota Layak Anak (KLA) di Kota Surakarta, dapat merumuskan komponen komponen untuk mengetahui kesesuaian taman cerdas sebagai ruang publik skala pelayanan kelurahan terhadap Konsep Kota Layak Anak (KLA) di Kota Surakarta selain komponen lokasi strategis, ketersediaan fasilitas bermain dan dan belajar sesuai dengan kebutuhan anak, lingkungan yang aman dan nyaman, serta keamanan dan kenyamanan agar penelitian ini dapat lebih berkembang serta penelitian selanjutnya dapat meninjau keterkaitan maupun hubungan keempat klaster tersebut dalam mendukung perwujudan Kota Layak Anak (KLA) di Kota Surakarta.

\section{DAFTAR PUSTAKA}

Bartlett, Sheridan. (2002). "Urban Childern and the Physical Environment". Amman, Jordan: International Conference on Childern and The City.

Carr, Stephen,et al. (1992). Public Space. Cambrige University Press : United States of America

Chiara, De Joseph, et al. 1995. Time Saver Standards for Housing and Residential Development. $2^{\text {nd }}$ Edition. United States of America : McGraw-Hill, Inc

Darmawan,E. (2009). Ruang Publik dalam Arsitektur Kota. Semarang:Badan Perbit Universeitas Diponegoro

Ditjen Cipta Karya Departemen Pekerjaan Umum Tahun 1997 tentang Kamus Tata Ruang

Hakim, Rustam dan H.Utomo. (2003). Komponen Perancangan Arsitektur Lanskap Prinsip Unsur dan Aplikasi Desain. Jakarta : Bumi Aksara

Hastuti. (2012). Psikologi Perkembangan Anak, Jakarta: Suka Buku

Joga,N, (2013). Gerakan Kota Hijau. Jakarta : PT Gramedia Pustaka Utama 
Kementerian Pemberdayaan Perempuan dan Perlindungan Anak Republik Indonesia. 2013. Profil Anak Indonesia.

Peraturan Menteri Pekerjaan Umum 05/PRT/M/2008 tentang Pedoman Penyediaan Pemanfaaatan RTH DI Kawasan Perkotaan

Peraturan Menteri Pemberdayaan Perempuan dan Perlindungan Anak Republik Indonesia Nomor 11 Tahun 2011 tentang Kebijakan Pengembangan Kabupaten/Kota Layak Anak

Profil Anak Kota Surakarta tahun 2013 berdasarkan Bapermas PP,PA, dan KB Kota Surakarta

Peraturan Walikota Surakarta Nomor 6 Tahun 2008 tentang Prosedur Pelaksanaan dan Prosedur Pelaksanaan dan Pengelolaan Taman Cerdas.

Riggio, E (2002). Child Friendly Cities: Good Governance in the Best
Interests of the Child, Environment \& Urbanization, vol. 14 , no. 2 , October, pp. $45-58$

Shirvani,H.(1985). The Urban Design Process. New York : Van Nostrand Reinhold Company.

Undang - Undang Nomor 26 Tahun 2007 tentang Penataan Ruang

UNICEF IRC. (2004). Building Child Friendly Cities, A Framework for Action. UNICEF Innocenti Research Center.

Yusuf, Syamsu. (2004). Psikologi Perkembangan Anak dan Remaja, Bandung: Remaja Rosdakarya

Widiyanto, (2012). Lingkungan Kota Layak Anak (Child Friendly City) berdasarkan persepsi orang tua di Kota Yogyakarta. Jurnal : Bumi Lestari, Yogyakarta 